\title{
Strategies to Enhance Input Use Efficiency and Productivity of Sugarcane through Precision Agriculture
}

\author{
Gulzar S. Sanghera* \\ PAU, Regional Research Station, Kapurthala, 144601, Punjab, India \\ *Corresponding author
}

Keywords

Sugarcane, sugar recovery, water use efficiency, food security, drip irrigation, fertigation

Article Info

Accepted:

20 May 2021

Available Online:

10 June 2021
Application of diverse conventional and non-conventional approaches/ technologies for sugarcane improvement meet problems of complex genome, narrow genetic base of crop, genetic recombination, and poor fertility coupled with long breeding cycle. To sustain the production, productivity of sugar industry in rational manner, it is imperative to counsel sugarcane farmers for the selection of ideal varieties based on growth duration and maturity groups, planting crop season and kind of crop (plant/ratoon) to be taken. Recently, precise technological interventions viz. sub-soiling, mechanical weeding and wider row spacing ( $4 \mathrm{~m}$ paired row trench planting), intercrop cultivation (wheat, cabbage, garlic, sarson, onion etc.), quality seed production through tissue culture and single bud chip nursery raising have augmented per unit area productivity of sugarcane crop. Besides, to enhance input use efficiency in sugarcane cultivation especially judicious use of water through micro irrigation techniques (subsurface drip and fertigation), site specific nutrient management etc., and integrated management pest and diseases have rewarded the growers and industry in terms of higher cane production and sugar yield. Therefore, in order to sustain cane crushing in sugar mills and its sustenance towards national food security, the development of new varieties capable of giving higher cane yield and sugar recovery along with field stability and good ratoon ability, adoption of suitable time and method of planting, promotion of intercropping, mechanization for planting, strengthening of seed production programme, water management, integrated nutrient management approach, integrated pest management and refinement of agro-techniques for sustainable sugarcane farming system are presented in this chapter. Therefore, for making sugarcane farming a sustainable and profitable enterprise towards national food security, the credit flow and its proper utilization have to be ensured through regulatory framework. 


\section{Introduction}

Sugarcane is a glycophyte, sucrose storing member of tall growing perennial monocotyledonous grass. It belongs to the family Gramineae and genus Saccharum $L$. (Price, 1967; Arceneaux, 1967). Globally, more than a hundred countries that are located between latitudes of about $40^{\circ}$ degrees North and South of the equator grow sugarcane commercially for sugar and bio-fuel. Differences in climatic variables, types of soil conditions and differential farming practices result in crops with widely differing yields grown for anything from 9 months to 2 years between harvests (Dunckelman and Breaux, 1970). Green cane yields (at natural moisture content) per hectare expressed in tonnes ( $t)$ ranges from 20t to over 200t. This is the quantum of material as harvested; represent about $60 \%$ of the above-ground biomass. It has been reported (FAO, 1981) that an annual yield of 100 green tonnes (equivalent to 30 dry tonnes) would be regarded as an ideal average for almost any region, with current national averages of about 80 green tonnes per hectare for all the developed countries and averaging about 54 tonnes per hectare in developing countries; these yields have been more or less stagnant over the years. Sugarcane is being a long duration crop (12-14 months), faces various abiotic stresses like shortage of water (Gulati and Banerjee, 2016; Sanghera and Kumar, 2018), extreme temperatures (high and low) during summer and winter (Sanghera 2020), flooding during rainy season (Avivi et al., 2016), nutritional stress, salinity, alkalinity (Elordi et al., 2020) and biotic stresses like fungal diseases as red rot, smut, wilt, rust, pokkah boeng, grassy shoot disease by phytoplasma, bacterial (Vishwanathan and Rao 2011; Sanghera and Malhotra, 2018), insect pests like sugarcane borers complex, pyrilla, black bug, wooly aphid, scales, white fly, mille bugs and white grub etc., are also responsible for reduction in cane and sugar yields/ productivity (Sanghera and Kumar, 2018). By excess use of irrigation and chemical fertilizers, the soil has been degraded causing the problems in sustainability of the crop (Sanghera et al., 2018). Sugar industry has been plagued with several problems which call for immediate attention and rational solutions. Further, sugarcane cultivation and processing plays an important role in the economic growth of sugarcane growing regions and, hence, any improvement in its production and productivity will surely help in economic growth and prosperity of the growers and other associated stakeholders (Martínez et al., 2013; Sanghera et al., 2018). The deficit in the demand and supply of the sugarcane production in the command area of sugar industries hints at the non-realization of resources to the optimum level over the years. The reason might be lower adoption of improved sugarcane production technology. Development of new technology is generally not a major problem but the difficulty is that of acceptance and diffusion of these techniques by the farmers. To enhance and sustain the output and profitability in the sector, on farm production and productivity of cane and the recovery rate of sugar in mills needs to be increased in a systematic manner. To attain high cane and sugar yields and better returns from sugarcane cultivation, there is need to reduce the costs of cultivation, improve the input use efficiency by adopting the latest technological interventions; use improved high yielding varieties of sugarcane, to have rapid varietal replacement rate; seed replacement rate through multiplication of disease-free seed of new cultivars, that help to safeguard the interests of cane farmers and the sugar industry. A number of techniques for better cane production, protection, mechanization and seed propagation have been recently developed by different research organisations that need to be practically and successfully adopted by cane growers through sugar industry to harness better outputs in 
term of cane and sugar yields for sustaining both sugar industry and farming community in sugarcane growing countries. In this chapter, attempt has been made to provide a comprehensive review of the important and advanced cane production technologies for precision sugarcane agriculture and input use efficiency, seed quality assurance and their role in food security based systems.

\section{Basic inputs for Sugarcane Agriculture}

Sugarcane is grown between $35^{\circ} \mathrm{N}$ and $35^{\circ} \mathrm{S}$ latitude from sea level to $1600 \mathrm{~m}$ above sea level. It is cultivated on a variety of soils around the world from loamy sand to clay. It requires a temperature of $24^{\circ} \mathrm{C}$ to $30^{\circ} \mathrm{C}$ and an evenly distributed rainfall/irrigation of 2000 $\mathrm{mm}$ for optimum growth (Anonymous, 2017a). Thus, tropical climate is the most suitable for sugarcane cultivation. However, the sugarcane crop is also being successfully grown in subtropical areas. Sugarcane is being a long duration crop taking 8-20 months for its maturity, based on climatic conditions of the region where it is grown after being planting as stem cuttings or sett pieces (Barnes, 1974). In general, the 'first crop' after planting is harvested after about 12-14 months in a year; to get sustainable cane yield and better returns from this crop, 'ratooning' after regrowth of first harvest is followed that saves cost of fresh cane seed, until a reduction in yield indicates the need for fresh replanting. The exact number of ratoon crops to be taken depends on various factors like the length of time between consecutive crops, and time of harvesting and techniques used (manual or mechanical) that varies widely among different cane-growing regions (Shahi et al., 2003). The highest cane and sugar yields are obtained when cane crop experience with a long warm growing season during formative stage and cooler cum drier period followed during maturation and ripening stage that should be free from frosts days. Further, sugarcane ripening or maturity (i.e. accumulation of sugar in the lower portion of the stem) may also be enhanced/ encouraged through deprivation of water, by lowering nitrogen application in later formative stage, while in some special circumstances by application of plant growth regulating chemicals known as cane ripeners (Bull and Glasziou, 1963; Mamet, 1999). In other words, ripening process can thus be regarded as a stressful response because it is preferred by the conditions which restrict vegetative/ formative growth stage. Miller and James (1977) suggested that higher yields of total dry matter might be expected, if cane were bred and grown for total biomass, rather than for sucrose content and juice purity as done presently. Therefore, to attain higher yields, considerable quantity and application of fertilizer is essential. For example to harvest a crop produce of $70.0 \mathrm{t} / \mathrm{ha}$, it may require 100 $\mathrm{kg} \mathrm{N}, 60 \mathrm{~kg}_{2} \mathrm{O}_{5}$ and $30 \mathrm{~kg} \mathrm{~K}_{2} \mathrm{O}$. Some part of it may be released into the field in the form of burning dead leaves/ trash of the crop before/after harvest, as well as returning boiler ash and/or filter mud to the field. Sugarcane can grow on wider range of soil types if sufficient quantity of irrigation water is available during crop season (about 150 $\mathrm{cm} /$ year). Jackson (2005) suggested that the quantum of good quality irrigation water is about $1 \mathrm{t} / \mathrm{kg}$ sugar produced per year in the crop season.

Different production systems vary with respect to vertically integrated plantations with agriculture sector, transport and processing controlled by a single management system routinely followed in the developed countries and the small farmers selling to central processing stations (Chen 1985). Traditionally cane harvesting was done manually by hand and sugarcane cultivation was considered to be very labour intensive. Over the last two decades there has been a shift towards mechanical harvesting, but the 
cost of machinery is high that needs to be explored on custom hiring basis to help and sustain small scale farmers.

\section{Scope of precision agriculture in sugarcane}

The main objective of precision farming/ cultivation is to improve per unit area productivity as well as total production of crop with minimum environmental hazards along with reduction in overall cost of cultivation (Robert, 1999). To manage variability in landscape / topology, use of differential and variable rate technology, site specific planting techniques, site specific nutrient management and other input use precise land levelling is an important intervention (Jat et al., 2004) in sugarcane agriculture. For ideal crop establishment, the crop inputs should be distributed on a spatially selective basis through gird sampling or zone management approach. During last two and half decades, there is indiscriminate use of irrigation water, pesticides and imbalanced use of fertilizers because India, being a land of geo-physical, agro-climatic and greater socioeconomic variability. It badly needs precision farming for increasing use efficiency of different crop inputs especially in sugarcane crop that also help in maintaining the sustainability with enhanced productivity and reduced environmental damage. Various discussions and conversations elaborated on the topic provided the definition of precision farming as the application of different technologies and principles to manage spatial and temporal variability associated with all related aspects of agricultural production for the purpose of improving crop performance (production and quality) keeping in view the environmental quality factors. Therefore the main objectives of precision farming are focussed to increase crop production efficiency, improve product quality, use of chemicals more efficiently, energy conservation and soil and ground water protection (Sharma et al., 2005).
Sugarcane being C4 grass plant is most efficient for converting solar energy into sugars. Initially, Polynesians cultivated canes for its sweetness (Artschwager et al., 1958) and was well adapted to such conditions but later on now its various by-products and other uses like paper, ethanol and other alcohol, animal feed, antibiotics, particle board, biofertilizer and for electricity generation were reported from all over the world (Sanghera $e t$ al., 2018) because of which its precision cultivation is a must.

Sugarcane industry run in parallel to the growth of human civilization and is as old as agriculture. For improving the benefits in cane farming, recovery rate in terms of brix of sugarcanes in mills while extraction is required and that could only be improved by adopting the complete set of precision sugarcane farming (Stafford, 1996; Pierce et al., 1999) which reduces the cost of cultivation. Conventional crop management practices from last many decades in India is capital, labour and water intensive which ultimately results in poor yields and thus returns. That's why new generations of farmers refused to get involved in the farming and tried to get some government jobs or settle abroad. Precision sugarcane farming's practices (most scientific and modern approaches) for improving cane yield as well as quality gaining momentum in 21 st century.

\section{Recent crop establishment techniques for sugarcane}

Despite much progress in mechanization, use of country ploughs for tillage is not obsolete in India. Germination, crop stand, vigour and yield are dependent on proper tillage and crop establishment methods. Simply, mechanization does not ensure precision therefore, low cost precision planters with precise seed metering devices are to be popularized to ensure optimum plant stand 
with less seed rates. The recent approaches of conservation agriculture with the development of precision planters viz. no-till multi-crop planter with new generation seed metering systems reduced till raised bed planter with multi-crop planting systems in one of the right direction of precision farming in Indian perspective and can be properly followed when the soil physico-chemical variability and constraints are well known (Sanghera et al., 2020). Generally, deep ploughings (4-6) are required to produce good tilth in field to prepare land for sugarcane planting. However, ploughing must followed after each ploughing to pulverize the soil for better soil texture and aeration.

\section{Sub-soiling}

It is a process of deep tilling of the ground mainly practiced to un-compact the soil that has occurred due to use of heavy machinery in present day farming.

It also improves aeration of the soil and diffusion of nutrients (Raper et al., 1998)). Deep crisscross sub-soiling $(1.0 \mathrm{~m})$ would incorporate the subsoil with the top soil and must be repeated after every 3-4 years.

Generally, chiseler used for this purpose which breaks the hard pan, improves the water and air movements, increased water infiltration rate which further helps in better rhizosphere area from where sugarcane could extract the nutrients from the soil solution (Kumar et al., 2012)., thereby enabling plants to better withstand short term anaerobic conditions (Carter et al., 1996; Raper et al., 1998). Further, Kumar et al., (2012) reported that sub-soiling in sugarcane crop is helpful in improving juice quality, sugar yield and profit. Sub-soiling practice is beneficial in ameliorating soil compaction problem arises due to use of heavy machinery in rice wheat cropping system.
Tractor operated multi row rotary weeder for weeding

Manual weeding in sugarcane crop is laborious and time consuming and hence efficient mechanical weeders are being developed to obtain good yields. The purpose of weeding cum inter-culture operation is to provide ideal conditions for initial crop establishment and its vigorous growth (Olaoye and Adikanae, 2006). Both mechanical and chemical methods are effective for weed management 1 but mechanical method is preferred to chemical method because a) weedicides are expensive and b) some weedicides are selective to specific weeds and also sometime injurious to crops and human beings. Sometime efficacy of weedicides is also affected by environmental conditions at the time of their application rendering them ineffective. The cost of operation per hectare for two passes is Rs.3400. The cost of weeding by conventional method is Rs.7050 (Anonymous, 2006). The savings in cost in comparison with the manual method is $52 \%$, whereas the saving in time is $78 \%$ (Table 1 ). On the other hand, mechanical weed management makes the soil surface loose which results in better soil aeration, moisture conservation which helps in better root development, thus enhancing quality as well quality of crop produce.

\section{Wider row spacing for mechanical harvesting}

Sugarcane farming is very labour intensive and requires heavy use of machinery. The increase in labour wages as well as its scarcity has led to enhanced dependency of growers on farm machinery in different operations. In order to make use of the equipment to be economically viable, growers must consider factors such as the cost of the equipment in relation to the operation and utilization of equipment, the limitations and suitability of 
the equipment, slope of the land, field access and other factors such as soil compaction and crop damage and harvesting losses. Wider row spacing is preferred for mechanisation and should be compatible with the wheel tracks of infield machinery and equipment to avoid cane stool damage. The cane sets must be planted at $120 \mathrm{~cm}$ row spacing or by using 120:30 cm paired row trench method. This will help in mechanical harvesting of sugarcane. When harvesting mechanically, the variety should also have the attributes like non-brittle cane to reduce losses, resistance to lodging, minimal tops and trash, selftrashing or loose leafed to facilitate trash removal and ratoon ability (Sanghera et al., 2018). Chopper harvesters have however met most of the requirements of harvesting under a larger range of conditions, slopes, lodged cane, green cane, and topping requirements.

\section{Techniques for breaking cane yield ceiling}

The yield declaration, stagnation and decline observed in high yielding environments have become a danger signal in sugarcane production. The cane production and productivity have reached a yield plateau during last two decades (Sanghera et al., 2014). It is thus imperative to find ways and means to lift the present yield level, due to adoption of high-yielding varieties (HYVs), optimize the use of various inputs such as water and fertilizer, in order to make the sugarcane production efficient, cost effective, and suitable for resource poor farmers, sustainable and environment friendly (Sanghera et al., 2016a). Many improved sugarcane varieties (both early and mid-late group) have been recently released for general cultivation sugarcane growers and sugar industry for high yield and sucrose per cent (Sanghera et al., 2016 b; 2016 c) (Table 1). The releases of new varieties have added to varietal diversity in their respective maturity groups and will help in sustainable sugarcane farming (Sanghera et al., 2018). Sugarcane plays a significant role in Indian agriculture being a major source of white sugar in the country. It is cultivated in an area of $5.3 \mathrm{~m}$ ha with an average productivity of $70.8 \mathrm{t} / \mathrm{ha}$ in country while the corresponding figures for Punjab state is 94.0 thousand hectares and 81.3t/ha, respectively (Anonymous, 2019). It is strongly influenced by the impacts of longterm climatic change as well as local weather and seasonal variations. The climate affects the growth and development of plants and may harm the crops (Sanghera and Kumar, 2018a). Potential direct/indirect effects of climate change on the agricultural systems have been identified which include: seasonal changes in rainfall and temperature could impact agro-climatic conditions, altering growing seasons, planting and harvesting calendars, water availability, pest, weed and disease populations, transpiration, photosynthesis and biomass production is altered along with land suitability (Sanghera et al., 2018; Sanghera and Kumar, 2018b)

\section{Quality seed assurance in sugarcane}

Sugarcane yields are deteriorating day by day because of lack of good quality seed (Mall et al., 2018; Yadav 2009) Recovery of sugar also come down because of poor quality canes due to lack of availability of optimum climates required for cane development (Binbol et al., 2006; Gawander, 2007). It is also strongly influenced by the impacts of long-term climatic change as well as local weather and seasonal variations. The climate affects the growth and development of plants and may harm the crops (Sanghera and Kumar, 2018a). It also affects severely on the microorganisms related directly or indirectly for better growth and yield of the crop (Sanghera and Sharma, 2011). Potential direct/indirect effects of climate change on the agricultural systems have been identified which include: seasonal changes in rainfall and temperature could 
impact agro-climatic conditions, altering growing seasons, planting and harvesting calendars, water availability, pest, weed and disease populations, transpiration, photosynthesis and biomass production is altered along with land suitability (Rosegrant et al., 2008; Sanghera et al., 2018a; 2018b).

Inadequate availability of quality seed of new sugarcane varieties and poor seed replacement rate adversely affect the realization of potential cane yield of varieties (Salokhe, 2016). Seed replacement with fresh commercial seed is done only after 4 years (Sundara, 2000). Diseases are one of the major constraints in the profitable cultivation of sugarcane. Sugarcane is vegetatively propagated and it favours accumulation of pathogens of most of the diseases. Hence along with seed canes disease causing pathogens are also introduced into new areas. Slow accumulation of different pathogens over a period of time makes minor diseases into major one. Several epidemics due to red rot, smut, wilt, grassy shoot, ratoon stunting, yellow leaf and leaf scald occurred in the past indicated that disease infected seed can played significantly in their creation and further spread (Vishvanathan and Rao 2011; Sanghera and Kumar, 2018b). Affected planting material poses a major problem in propagation and exchange of germplasm, and eventually in breeding and distribution of superior genotypes (Pathak 2009; Reddy and Sreenivasulu, 2011).

As sugarcane is vegetatively propagated for commercial cultivation and requires huge quantity of seed. Different kinds of planting materials viz., cane setts; settlings and bud chips are used for raising sugarcane crop. Stem cuttings or sections of the stalks called "setts" propagate sugarcane. Each set contains one or more buds. Cuttings are taken from the selected canes. The normal practice in sugarcane growing states of the country is to use commercial crop of sugarcane for seed purposes. Sugarcane yields and recovery of sugar deteriorate because of lack of good quality seed. Inadequate availability of quality seed of new sugarcane varieties and poor seed replacement rate (SRR) adversely affect the realization of potential cane yield of varieties (Sanghera and Kumar, 2020). Diseases are one of the major constraints in the profitable cultivation of sugarcane. Sugarcane is vegetatively propagated and it favours accumulation of pathogens of most of the diseases. Hence along with seed canes, disease causing pathogens are also introduced into new areas (Pathak, 2009; Sanghera and Kumar, 2018b). Affected planting material poses a major problem in propagation and exchange of germplasm, and eventually in breeding and distribution of superior genotypes. To obtain disease-free seed, a separate seed nursery should be maintained (Sandhu et al., 2000). It is not recommended to use the commercial crop for seed, as many pests and diseases go un-noticed in commercial crop.

\section{Sugarcane Micro-propagation}

It is another alternative technique to solve the chronic problem of low multiplication of seed. It is the clonal propagation of sugarcane where planting material is multiplied rapidly without impairing the genetic purity. Lee (1987) showed that a better way of micro propagation is shoot tip culture as plant obtained from mother plants has similar phenotypic character. Besides, studies have illustrated that there are many other benefits of using such a technique for development of cane by this method such as increase multiplication rate of new released varieties (Sreenivasan 1995; Sandhu et al., 2000), better cane stalk health, diseases free plants, application of this technique especially for storing the germplasm of canes (Ali et al., 2008; Mamun et al., 2004). Micro-propogation is not only a 
popular mean of clonal propagation but also the most viable and successful method for the production of pathogen free seed material (Sugiyarta and Winarsih 2008; Salokhe, 2016). This technique can be used for large scale production of newly released sugarcane varieties in order to speed up the sugarcane breeding process and for rejuvenation of outstanding old varieties (Belete, 2017).

A number of micro-propagation techniques suitable for commercial seed production in sugarcane have been reported. Apical meristem culture was used by Coleman (1970) and Hendre et al., (1975) to obtain sugarcane mosaic virus free plants. Axillary bud culture was applied successfully by Sauvaire and Galzy (1978) to produce true to type clones in many sugarcane varieties. Hendre et al., (1983) standardized an apical meristem culture technique for rapid multiplication of mosaic virus-free plants of variety Co 740 . Sreenivasan and Jalaja (1981) standardized micro-propagation technique based on the use of apical meristem with two or three leaf primodia (meristem tip) as the explants. Micro-propagation is the first major and widely accepted practical application of plant biotechnology.

It is a key tool of plant biotechnology that has been extensively exploited to meet the growing demands for elite planting material in the current century. Sugarcane micropropagation involves the use of small explants (meristems) which are cultured on a nutrient medium under sterile conditions. Using the appropriate growth medium and growing conditions explants can be induced to rapidly produce multiple shoots, and, with the addition of suitable hormones produce new roots (Jalaja et al., 2008). Sugarcane micropropagation is the practice of rapidly multiplying stock plant material to produce a large number of progeny plants under aseptic conditions using modern plant tissue culture methods. This is a simple method because of the ease of multiplication, saves cost of producing planting material (Fig 1) (Kaur and Sandhu, 2014). Micro-propagated sugarcane plants are used as breeder's seed in seed multiplication system and seed obtained from micro-propagated plants are used as foundation seed (Tawar, 2006). The plants should be spaced $60 \mathrm{~cm}$ apart with a row to row to spacing of $90 \mathrm{~cm}$, followed by immediate irrigation (Sandhu et al., 2009).

\section{Bud chip technology}

Cane setts with roots and shoots are known as settlings. These can be raised either in nursery beds or in polythene bags. Single node settlings are used as a planting material in spaced transplanting technique of raising sugarcane crop (Indian Institute of Sugarcane Research, Lucknow evolved a planting method namely, spaced transplanting technique (STP) (Sinha 2006; Shrivastava et al., 2006). Settlings are raised by planting single bud setts in nursery about a month before transplanting in the main field. For transplanting one hectare of field, approx. 50 $\mathrm{m}^{2}$ area of land and 2 tons of seed cane are required. This technique ensures higher stalk population (>1.2 Lakh canes $\left.\mathrm{ha}^{-1}\right)$ with uniform crop stand and higher average cane weight. lower incidence of pests and diseases and reduced crop lodging (Samant, 2017). It improves the ratio of seed cane to output from 1:10 to 1:40 (Table 2). This technique saves seed cane to the tune of $4 \mathrm{t} / \mathrm{ha}$. Raising seedlings through bud chip/ single bud technique is now the major frontier seed multiplication technique in sugarcane (Singh et al., 2011; Jain et al., 2014). In conventional system, about 6-8 tons seed cane /ha is used as planting material, when propagated by stalk cuttings consisting of 2 to 3 bud sett. Establishing the sugarcane crop using bud chips in place of setts could save about $80 \%$ by weight of the stalk material (Sahoo, 2014), 
however this technology has not been scaled up at commercial levels due to poor survival of bud chips under field conditions. So, it is advised to prepare a pre-hand nursery of seedlings from bud chips and then transplanting the seedlings in field at an appropriate time.

\section{Intercropping in sugarcane to harness better returns}

Sugarcane is the second cash cum-industrial crop. It is a long duration crop for cultivation which needs about 12-13 months from transplanting to harvest. Sugarcane is a wide spacing crop usually planted at 80 to $120 \mathrm{~cm}$ row to row spacing (RRS). For full canopy development it needs 3-5 months and therefore, allows selective short duration intercrops. Intercropping in sugarcane has long been practiced to get interim monetary return. It is an excellent technique to increase total yield, higher monetary return, greater resource utilization and fulfill the diversified need of farmers (Singh et al., 1986). Different intercrops such as potato, mustard, onion, lentil, tomato, garlic, chickpea, coriander etc., have long been intercropping in sugarcane (Sanghera et al., 2020). Generally single intercrop in sugarcane is well practiced in cane growing regions. Inter-cropping in sugarcane generally requires more labor, thereby creating productive employment opportunities and generating higher income. Many studies indicated that inter-cropping with sugarcane increase the grower's net income, create the employment opportunities for landless and owner household families. Intercropping also improves nutritional quality of diet for the farm family (Khan et al., 2005), allows better control of weeds, increases land equivalent ratio (Imran et al., 2011) and has some beneficial effects on pest and disease control (Abdullah et al., 2006). Further being long duration exhaustive crop sugarcane caused soil fertility decrease (Razzaque et al.,
2007). Intercropping protect soil from fertility decrease of soil and also improve soil health (Ahmed et al., 2007). Therefore it is also a profit to be considered, where next crop will be benefited economically with intercrops compared to sole crop. Intercropping legumes with sugarcane could be an option to maintain soil fertility. In consequential intercropping with sugarcane it will be better to consider a leguminous crop for better soil health. Summer mungbean could be grown as second intercrop after harvesting mustard/soybean and the plant biomass could be incorporated in between the cane rows for improving soil fertility (Hossain et al., 1995). Furthermore, intercropping is helpful to control weed infestation, reduces pest disease infestation, gives yield advantage and there is stable yield over time and improves nutritional quality of diet for the farm family (Ibeawuchi 2007 and Kashem et al., 2007). Intercropping provides insurance against crop failure and/or better avenue of employment for the rural people (Ibeawuchi, 2007). Introducing the double intercropping might play a wonderful role in providing interim return. Therefore, to harness better returns or enhanced productivity per unit area it is beneficial to grow it with other small duration crops suitable for different planting seasons. Thus it is a sustainable way of sugarcane popularization (Sanghera et al., 2018a; Islam and Islam, 2018).

\section{Integrated insect-pests and disease management}

It is a systematic approach used to achieve minimal economic damage to the crops by any natural pest. IPM (Integrated Pest Management) takes into account all the six crop protection mechanisms, namely chemical, biological, bio-technical, agronomic practices, physical procedures and plant quarantine. As many other tropical crops, sugarcane hosts an important quantity of insects and diseases, some of them being of 
economic importance for the sugarcane farmers and the industries (Goebel and Salam, 2011; Sanghera and Kumar, 2018b). Sugarcane crop is attacked by a wide range of insect pests all through its plant stages (Box 1953; Williams et al., 1969). Though majority of these are minor pests, a few major pests exist and cause significant damage to all parts of the crop (i.e. root, stalks and foliage) (Williams et al., 1969; Hall, 1988). As many small-scale farmers in developing countries rely heavily on income generated through sugarcane production, losses from pests and diseases can significantly impact on these communities, while the incursion by a new pest or disease could lead to devastating consequences. Sugarcane is being an annual crop and attacked by number of insect-pests and diseases. They can cause economic and qualitative damage to the crop. Management of insect-pests and diseases of sugarcane crop is promising and selection of effective management strategy is equally important (Sanghera et al., 2018a). First of all regular monitoring of crop is required. If crop is infected at negligible level, agronomical/ cultural/mechanical practices should be adopted. If crop is grown in insect pests and disease prevalence area, prior management strategy is required like selection of resistant varieties, sett treatment with bio-control agents or agro-chemicals to minimize population of infection causing agents (Sanghera et al., 2020). In standing crop, management of insect pests and diseases is difficult. However, some agro-chemicals are recommended for their management. So agrochemicals should be procured from registered agency or government organizations and methods should be understood properly. To minimize all the ill effects of chemical pesticides and maintain the pest population at minimum level, integrated pest management is the only way to manage the pests within the threshold level and sustain production and productivity. Despite many years of implementation of pest management strategies, some pests remain difficult to manage and their dynamics are still largely unpredictable, with sometimes dramatic yield reduction (Kiritani 2006; Gregory et al., 2009). However, such management practices have been largely overlooked by cane growers (Shanthy et al., 2019).

\section{Use of bio-fertilizer in sugarcane}

It has been observed in recent years that yield of sugarcane has reached a plateau due to decline in factor productivity (Yadav et al., 2009). Current soil fertility improvement strategies are mainly focused on use of inorganic chemical fertilizers, which are not sustainable in the long run both in terms of ensuring continual soil health and also nonviable economics of cultivation. Apart from this, adverse effects of inorganic fertilizers on soil properties as a whole and serious threat to human health and environment necessitates use of organic manures and bio-products especially to improve soil biological properties (Babu et al., 2007). A soil without adequate biological organisms can be in all aspects termed as lifeless. The exploitation of beneficial microbes as a bio-fertilizer has assumed paramount importance in agriculture sector for their potential role in food safety and sustainable crop production. Plant Growth Prompting Rhizobacteria (PGPR) in the biofertilization of crops has been a well known fact that these PGPR strains may promote growth either by fixation of atmospheric nitrogen or by solubilization, if minerals such as phosphorous and they can also promote growth production of plant growth regulators. The occurrence of Azospirillum, Azotobacter, Pseudomonas and Bacillus in the rhizosphere of many plants have been well documented earlier (Rajasekar and Elango, 2011). Application of Azotobacter/Consortium biofertilizer @ 4 $\mathrm{kg} / \mathrm{acre}$ in the furrows at the time of planting 
would be helpful in increasing the cane yield. Bio-fertilizers play an important role in achieving this goal in an eco-friendly manner by fixing nitrogen, improving the crop growth by production of growth promoting chemicals and improving the nutrient uptake of the crops (Babu et al., 2007). Association of several bacterial genera and high nitrogenase activity in sugarcane crop has been reported (Boddey et al., 1995). For quite a long time now, biofertilizers are being recommended for sugarcane crop by the researchers and the impact of the technology has been demonstrated to the cane growers. However, social surveys indicate that adoption of this practice is still a reservation by many cane growers (Shanthy, 2012; Shanthy and Venkatesaperumal, 2018).

\section{Input use efficiency and productivity enhancement in sugarcane}

Yields of field crops have decreased due to the advent of increasing water scarcity in this century. The water is a very limiting input in this region for the crop production; its efficiency is quite low in the range 30-40 per cent, thereby about 60-70 per cent of irrigation water is lost during conveyance and application (Singh et al., 2012). Irrigation farming, the greatest water user of all, has been made responsible for inefficient water use. There is also not available new land for agriculture to meet the demand of ever increasing population in terms of food and clothing (Bhaduri, 2008). On the other hand, irrigation farming more and more has to compete with other interests for dwindling resources in water. Therefore, there is need to increase the yields and water use efficiency in water limited environments. Thus, for maximization of it should be focussed on the various water economization practices, irrigation scheduling based on consumptive pan evaporative, land configuration, selection of crop, varieties, intercropping, moisture conservation practices, use vegetative barriers, use of transpiration suppressants according to the availability of water (Sharma et al., 2004; Govaerts et al., 2005). Besides, the ecological aspect of water, depletion of groundwater resources, the concept of water use efficiency, need to improve the water use efficiency, factors to enhancing the water use efficiency which will help to sustain the resources of water and productivity of crops (Prihar, 2004). This section would be useful to convey the importance to work out the water use efficiency to indentify the efficient management practices, crop varieties/hybrids to get the higher productivity with the availability of water. With good management and adoption of appropriate practices improved agricultural water conservation and subsequent use of that water for more efficient crop production.

\section{Water use efficiency (WUE) in Sugarcane}

Water is a scarce natural resource. Its per capita availability is decreasing due to climate change and increased population, and has already reached to water stress line. Availability of water for agriculture is further decreasing as more and more quantity of water is being diverted for developmental activities and industrialization (Bos, 1985). Sugarcane is cultivated under widely varying conditions of soil type, rainfall pattern, temperature regimes and water availability (Marin et al., 2013; Sanghera and Kumar, 2018; Sanghera, 2020). Water requirement of sugarcane varies from 1200 to $3500 \mathrm{~mm}$ depending upon yield level, crop duration and climatic conditions. The water requirement varies from1200-1800 mm in the sub-tropical zone while it is 1600$2700 \mathrm{~mm}$ in tropical belt except for Maharashtra. The total crop water requirement is about $3500 \mathrm{~mm}$ for adsali cane in Maharashtra (Srivastava et al., 2011). Yates and Taylor (1988) in their comprehensive review gave WUE values ranging from 0.7 to 
1.45 tonnes of cane $/ \mathrm{ha} / \mathrm{cm}$ in different sugarcane growing regions of the world. In the tropical region, 30-40 irrigations are given. In the subtropical region, there are places wherein sugarcane is grown under rainfed conditions; there are places where only 3 to 5 protective irrigations are given during summer months and there are places wherein 15 irrigations are given (Yadav, 1991). In some places, the crop suffers water logging for some period necessitating the provisions of drainage facilities and moisture deficit some other period which warrants irrigation.

So, irrigation is given to supply adequate water to plants so as to obtain optimum yield and quality. It should be given at the optimum time so that the soil could supply water fast enough to meet the local atmospheric demands without placing the plants under any stress that would reduce yield or quality (Zadrazil, 1990; Yadav 1991). Sugarcane performs well when the soil moisture is in the upper range, very close to the field capacity.

It has been found that for sugarcane irrigation is to be given at $50 \%$ depletion of available soil moisture during the vegetative phage (from planting to 170 days after planting (DAP) and at75\% depletion of available soil moisture during the maturity phase (from 270 DAP to harvest) (Shih, 1989; Verma, 2004). Time of irrigation is decided based on physiological indications of the plant, soil moisture status or climatological data. Verma (2004) reported that sugarcane crop during its formative phase is irrigated once in 10-15 days in Punjab; once 10-12 days in Haryana; once in 7-15 days in Rajasthan; Once in 15-20 days in UP and Bihar. For efficient water management the artificial application of water (irrigation) to the root zone of the crop which is supplementary to rainfall, so as to provide optimum soil moisture condition in the root zone of the crop to realize its normal growth and yield. Hunsigi (1993) reported that under furrow irrigation nearly $90 \%$ of soil moisture extraction takes place in the first $60 \mathrm{~cm}$ of the soil layer. However the distribution of roots in the soil is strongly dependent on soil characteristics, cultivars and soil water content (Jones et al., 1990). In most places, rainfall is not uniformly distributed throughout the growing season of the sugarcane crop. In such situation, the crop will have to suffer water deficit at some stage or other. The objective of irrigation is to alleviate water deficit in sugarcane crop at time of insufficient rainfall (Inman-Bamber and Smith, 2005). Generally, the crops are irrigated based on either plant conditions or soil moisture status. Plant growth is related to the water balance in plant tissues. As soon as the water supply to the plant gets reduced, the physiological processes of the plants are disturbed and consequently growth parameters and yield are reduced (Sanghera et al., 2018b).

The physiological and morphological indicators of water deficiency like appearance of the plant, measuring the stomatal aperture, plant water content, leaf water potential etc. in plants could be used as a guide for deciding the time of irrigation. Similarly, depending on the ability of crop plants to extract water from the soil, the soil moisture status could be used to decide the time of irrigation (InmanBamber and Smith, 2005).

For sugarcane, it is necessary to maintain the moisture the moisture content of the root zone soil close to field capacity during the vegetative phase. In other words, the crop has to be irrigated before the depletion of $50 \%$ of the available soil moisture (Verma, 2004). Various methods to assess soil moisture include feel and appearance method, gravimeteric, electric resistance units, tensiometers and neuron scattering etc. Recently, various irrigation techniques have been suggested that can help to enhance water use efficiency in different crops. 


\section{Micro-irrigation system in sugarcane}

Sugarcane is one of the most important crops in the world. It plays a vital economic role in sugar and bioenergy production and has an important social role in the rural communities of sugar-producing nations worldwide. Climate change threatens the sustainability of most rainfed sugarcane farming systems (Knox et al., 2010). Some authors have reported that certain climate change scenarios may harm sugarcane growth and yield without the introduction of appropriate irrigation facilities (Santos and Sentelhas, 2012; Carvalho et al., 2015). Rainfed sugarcane farming systems are gradually being replaced by irrigated farming systems wherever such transition is possible. In addition, lowefficiency irrigation systems are being replaced by high-efficiency systems to make sugarcane farming more economically sustainable (Verma, 2004). However, irrigation is one of the most expensive practices of sugarcane farming systems and can account for more than 25\% of the production cost (Mazibuko et al., 2002; Narayanamoorthy, 2005). Therefore, the dimensions of sugarcane irrigation systems need to be adjusted for water conservation while simultaneously reducing operational costs.

\section{Drip irrigation}

Drip irrigation system considerably reduces the wetted land surface and applies water in such a quantity that it remains within root zone of the plants thereby making evaporation and percolation losses nearly zero (Kaushal et al., 2012). It results in higher number of tillers and millable canes than that from surface irrigated crop. It was observed that tiller mortality was higher in the treatments which gave higher number of tillers before onset of monsoon. Competition for nutrients, air, water and light due to overcrowding of tillers at one place might have resulted in tiller mortality (Ramesh and Mahadevaswamy, 2000). Subsurface drip irrigation enhances growth and yield, not only through the precise application of the right amount of water, but also by maintaining adequate aeration of the root zone (Pires et al., 2012). Further, it promotes the effectiveness of applied fertilizers by minimizing losses through processes such as denitrification, deep percolation and runoff, which can occur with other irrigation methods. The optimum depth of subsurface drip lines varies between 10 and $80 \mathrm{~cm}$ depending on the soil type, soil depth and crop type, as capillary action ensures water uptake by upward water movement (ElBerry et al., 2006; Hanafy et al., 2008). With the same amount of water, subsurface drip irrigation wets an area about 50\% larger than surface drip irrigation does. Mahesh et al., (2016) reported that subsurface and surface drip irrigation can save $31 \%$ and $23 \%$ of water relative to surface irrigation. They further reported significantly higher sugarcane yield and WUE with subsurface fertigation than with surface irrigation with a conventional fertilizer application. However, subsurface drip irrigation entails some drawbacks, such as low germination if there is poor capillary movement, salinity, nozzle clogging and uneven water distribution (Kaushal et al., 2012). Moreover, it does not always assure high efficiency and good yield because it requires an accurate design and a skilled operator (Dlamini, 2005). Therefore, new methods or strategies must be introduced to subsurface irrigation systems to achieve better precision, while overcoming the inherent disadvantages of available subsurface irrigation methods. Okinawa prefecture in Japan comprises many small islands with little or no surface water resources; therefore, sugarcane farming there requires waterefficient irrigation methods. However, drip irrigation, the most water-efficient method available is not popular among sugarcane 
farmers in the prefecture because it is labor intensive, requires frequent monitoring and many farmers are aged and favor lowmaintenance farming systems (Shukla and Lal, 2003; Narayanamoorthy, 2005). Therefore, water saving irrigation methods that can be operated with minimum attention are required to make sugarcane farming systems in Okinawa more sustainable and economically viable.

\section{Rain gun irrigation}

Normally sugarcane crop irrigated by flood irrigation or drip irrigation methods. In flood irrigation much more water needed for single irrigation. In drip irrigation water saving is possible but life of the system is very low 3 to 4 years due to salt sediment and rat bite problems (Dlamini 2005, Kaushal et al., 2012). So durable and efficient water saving rain gun system as the next revolution in irrigation methods was introduced which will runs without maintenance up to 50 years without fail (Shinde and Deshmukh 2007).

In a rain gun sprinkler irrigation system, water is piped to one or more central locations within the field and distributed by overhead high-pressure sprinklers or guns. Higher pressure sprinklers that rotate are called rotors and are driven by a ball drive, gear drive, or impact mechanism (Dinka 2016). Rotors can be designed to rotate in a full or partial circle. Guns are similar to rotors, except that they generally operate at very high pressures of 275 to $900 \mathrm{kPa}$ (40 to $130 \mathrm{psi}$ ) and flows of 3 to $76 \mathrm{~L} / \mathrm{s}$ (50 to 1200 US gal/min), usually with nozzle diameters in the range of 10 to $50 \mathrm{~mm}$ (0.5 to 1.9 in) (Chennakesavulu, 2014, Dinka 2016). When compared to flood irrigation method in sugarcane cultivation rain guns saves 3 times water, labor and time for irrigation to the same area (Hanafy et al.,. 2008,
Sivanappan 2014). But can change the climate also. During rain gun operation the relative humidity increase due to water particle spraying above the crops which helps to grow as rain effect. Some advantages and disadvantages of the system are as:

\section{Advantages of Rain Gun Irrigation System}

Highly Efficient Portable System

Long enduring and maintenance-free

Uniform sprinkling with the condition to calibrate droplet size and rainfall rate, suitable to all soils and crops.

Early sowing \& better germination of seedling through optimum moisture condition of soil which is possible by Rain Gun irrigation System.

Liquid fertilizer can be applied quickly over large areas. It saves on fertilizer quantity; foliar application hence results in good yield.

Reduces labor and pipeline cost

Reduces pest and insect attacks

This lessens the irrigation time and saves diesel

Prevents salination caused due to overirrigation thus maintaining soil productivity

\section{Disadvantages of Rain gun}

Large numbers of trees make it difficult to sprinkle uniformly.

The rain gun and the raiser pipes are very heavy.

High day time temperatures result in evaporation loss. 
Not suitable in areas with high-velocity winds.

Prohibitive cost of rain guns.

Repairs by qualified personnel

\section{Optimized subsurface irrigation system (OPSIS)}

The optimized subsurface irrigation system (OPSIS) is a new subsurface irrigation system for irrigating upland crops. It irrigates the root zone of the crop by capillarity (Gunarathna et al., 2017). OPSIS has two major components: a main water control system (including a solar-powered submersible pump, a water tank, a water supply column and a fertilizer tank) and a water distribution system (including a water distribution column at the head end of the field, perforated pipes buried parallel to the field surface to irrigate the field and PVC (Polyvinyl Chloride) or metal sheet to control seepage losses). Similar to the other subsurface irrigation systems, OPSIS is remarkable for its ability to eliminate surface runoff and evaporation (Chennakesavulu, 2014; Gunarathna et al., 2017). Further, it significantly reduces percolation losses, which are common problems in other subsurface irrigation systems (Gunarathna et al., 2017). Because a small solar-powered pump is used to lift water and create a pressure head and because minimum operational activities are required (Gunarathna et al., 2017), OPSIS offers the potential to drastically lower the operational costs of irrigation for sugarcane farmers in Okinawa. In OPSIS, water flow is automatically triggered by solar radiation (as it uses a solar-powered pump) without any manual operation, however it irrigates (emits water through perforated pipes) based on the soil moisture's potential difference between the inside of the pipe and the outside soil. Further, it can remain in place during other field operations, including mechanical harvesting (Chennakesavulu, 2014;
Gunarathna et al., 2017). In that respect, OPSIS is compatible with the low-intervention requirements of Okinawan sugarcane farmers. Further, as the farmers irrigate their fields prescriptively (set timing and amounts), rainfall that occurs shortly after scheduled irrigation application leads to water wastage, whereas OPSIS irrigates only when required. However, OPSIS is still new and has had little uptake in Okinawa as there is not yet sufficient information on it. OPSIS therefore needs to be compared with other irrigation methods in terms of both yield performances and water conservation, as water conservation is equally important in these small waterlimited islands. Therefore, we conducted cultivation experiments in Okinawa to quantify the differences between OPSIS and conventional sprinkler irrigation systems in terms of water consumption and several growth and yield parameters. Further, Gunarathna et al., (2018) reported that both irrigation methods consumed low amounts of irrigation water during the growing period of the first ratoon crop. However, the results showed that OPSIS $(82 \mathrm{~mm})$ consumed only $46 \%$ of the amount of water that was consumed by sprinkler irrigation $(178 \mathrm{~mm})$. During the second ratoon crop, the field received $2239 \mathrm{~mm}$ of rainfall, of which an estimated $1545 \mathrm{~mm}$ was effective. During this period OPSIS (323 mm) used $79 \%$ of the water used by sprinkler irrigation $(409 \mathrm{~mm})$. In the sprinkler irrigation, although antecedent rainfall was taken into consideration, irrigation timing followed the irrigation schedule decided in the region (Chennakesavulu, 2014). Therefore, more irrigation water was used than needed. On the other hand, OPSIS does not use much water when soil moisture is near saturation (Gunarathna et al., 2018).

Therefore, OPSIS used less water than sprinkler irrigation and the difference was greater when rainfall was average. The difference is attributed to OPSIS having more 
precise application, an absence of runoff and minimal evaporation compared with sprinkler irrigation.

\section{Site specific nutrient management}

From the last few decades, much of the discussions are there for improving nutrient use efficiency for overall having positive effect on the ecology. As per traditional knowledge farmers applied fertilizers as per use by their neighbouring farmers on the whole field without taken into consideration the spatial variability (Akinyemi and Adewale, 1984). Further, different sugarcane cultivars might have different nutrient requirements which further affected by the inherent nutrient supplying capacity of the soils (Shahi et al., 2003). Similarly, by the use of lesser fertilizer use than required also hinder the yield achievements as per their potentials. Therefore, both the higher or lower fertilizer usage is not required rather their adequate use is a must for the precision sugarcane farming which is the need of the time (Sanghera et al., 2020). Generally, fertilizer recommendations varied from field to field due to variations of field characteristics including soil organic carbon, soil texture, soil structure, soil nutrients, field topography and other properties. Sampling techniques of soil to describe field variability have been recommended (Linsley and Bauer, 19299). Before Global Positioning System (GPS) and Geographic Information System (GIS), delineating spatial variation is not an easy task and their effectiveness in the agricultural field depends on proper ground truth studies. Further, these techniques help us in studying complex spatial relationships between soil fertility factors. Soil sampling techniques that attempt to describe the variability in soil fertility factors within a field has gained more importance. Thus, precision agriculture through more judicious use of crop inputs and mapping of yield and quality variability, proved to be a tool which further helped to improve the overall sugarcane yields as well as quality. New techniques could reduce the total amount of nutrients and other inputs applied to a field and thereby also minimize variability of that input (nutrient). Increased crop quality, improved sustainability, lower management risk, increased food safety due to produce traceability, environment protection are some of the benefits of the precision agriculture (Robert, 2002). Site-specific nutrient management (SSNM) recognizes the inherent spatial variability associated with most fields under crop production (Bhatt and Hossain, 2019). SSNM practice responds significantly not only to the primary nutrients but also to the secondary and micro-nutrients due to emerging deficiencies for the targeted yields. SSNM tolls viz. leaf colour charts helps to consider the spatial variability within the field. It also took into consideration of the effect of different added inputs viz. farm yard manure or may also advocate the higher sue of the nutrients at some deficient sites, which otherwise ignored in the conventional methods, thereby resulting in lower production particularly in these pockets with lesser fertility. Among the most important soil factors influencing yield patterns, soil $\mathrm{pH}$, soil organic carbon (\%), extractable $\mathrm{Ca} 2+$ and $\mathrm{Mg} 2+$, K-Saturation, clay content $(0-15 \mathrm{~cm})$ and $\mathrm{N}: \mathrm{P}$ ratio are the main which must be considered (Ping et al., 2005). Site specific nutrient management within field on cluster basis coupled with target yield approach may further enhance the nutrient use efficiency and helps to sustained yield level of crops.

Sugarcane crop, after textile industry is the second largest agricultural industry impacting economy of a country, therefore, proper and judicious nutrient management played an important role. Attempts being made to improve the nutrient use efficiency by one or other way in the sugarcane farming. Integrated nutrient management also played an important 
role in this regard to sustain the soil health. Hence, water and nutrients management issues in sugarcane need to be addressed as early as possible in relation to climate. Sugarcane takes up nearly $208 \mathrm{~kg} \mathrm{~N}, 53 \mathrm{~kg} \mathrm{P}, 280 \mathrm{~kg} \mathrm{~K}$, $6.3 \mathrm{~kg} \mathrm{Fe}, 1.2 \mathrm{~kg} \mathrm{Mn}, 0.6 \mathrm{~kg} \mathrm{Zn}$ and $0.2 \mathrm{~kg} \mathrm{Cu}$ from soil by an average crop producing $40 \mathrm{t}$ acre $^{-1}$ of sugarcane (Malavolta, 1994) which indicates higher amounts of nitrogen and potassium need to be applied. Further, higher costs of these fertilizers appeal for their judicious use through newer technological options seems ideal. Among them wider/paired rows, drip/ fertigation and split application as per crop demand/ growth stage etc., are worthy for adoption (Sanghera et al., 2020) Further, nitrogenous fertilizer being a basic and widely applied nutrient in Indian agriculture wishes special attention. For improving nitrogen use efficiency, nitrogen losses and environmental pollutions should be reduced, through leaf color charts and chlorophyll meters (SPAD) (Shukla et al., 2004). The leaf color chart (LCC) based on real time nitrogen management can be used to optimize or synchronize nitrogen application with crop demand or improve existing fixed split nitrogen recommendations (Bhatt and Hossain, 2019). They further reported that the net returns in rice-wheat cropping system were increased by 19-31 in LCC based Nmanagement then in fixed time nitrogen application. The yield and yield attributes of rice were significantly higher in the LCC based nitrogen application compared to other treatments (Shukla et al., 2004; Budhar, 2005). The performance of LCC in sugarcane also needs to be tested for having need based application of $\mathrm{N}$-fertilizers to the canes.

\section{Conserving soil organic carbon content}

Incorporation of farm wastes (chopped trash, rice straw and legume husk) into the soil before sugarcane planting marginally increased soil organic carbon and nitrogen content but caused no significant changes in the available phosphorus and potassium contents (Yadav and Prasad, 1992). Maximum benefits however, were produced by the incorporation of legume husk. The results of this experiment confirm those of Yadav et al., (1987) who found that organic carbon content of different soils was increased when these were incubated with cane trash with urea. Similar results were obtained by Akinyemi and Adiwale (1984) who reported that additional doses of nitrogen accelerated the decomposition process of organic wastes thus increased the organic carbon content of the soil. The increase in organic carbon content of the soil might also be caused by the humification of cane trash and other farm wastes (Sinha et al., 1977).

Besides, increasing the organic carbon content, the initial decomposition of farm wastes immobilizes soil nitrogen because of the high carbon: nitrogen ratio of the wastes. This transformed nitrogen is slowly released as decomposition advances and immediately used by the sugarcane crop, so that none is lost by leaching. Because of their slow decomposition, farm waste materials serve as a better agent for solubilizing and chelating nutrients, which can then be utilized by a long duration crop such as sugarcane as they are made available. As a result of such gradual process, organic waste materials have residual effects which benefit the crop and help sustain yields on a long term basis (Yadav and Prasad, 1992). The enzymes and vitamins released during the decomposition of waste materials may also improve crop yields (Yadav, 1985).

\section{Use of slow release $\mathbf{N}$ fertilizers and nitrification inhibitors}

Certain products like gamma BHC, telodrin, $\mathrm{N}$-serve and a few others have been found to increase the efficiency of fertilizer $\mathrm{N}$ due to their nitrification inhibitory character when 
applied in soil at the time of planting. These should be used extensively to enhance $\mathrm{N}$ use efficiency in sugarcane (Yadav, 1985). Comparison of new $\mathrm{N}$ carriers like urea super granules (USG), neem-cake coated urea (NCU) and dicyandiamide treated urea (DCD) and the traditional source of $\mathrm{N}$, prilled urea (PU) to supply $150 \mathrm{~kg} \mathrm{~N} / \mathrm{ha}$ to sugarcane revealed that differences in yield resulting from use of the new carriers were not significant (Yadav et al.,. 1990). Uptake and recovery of $\mathrm{N}$ were significantly greater using USG, NCU, and DCD than using PU probably because of reduction in losses of $\mathrm{N}$ through volatilization and leaching when new carriers of $\mathrm{N}$ were used (Ram et al., 1988). The direct effect of nitrogen was $184 \mathrm{~kg}$ cane $/ \mathrm{kg} \mathrm{N}$ applied to ratoon crop but residual and cumulative effects of $\mathrm{N}$ applied to the plant crop on yield and quality of ratoon crop were small (Srivastava and Yadav, 2017). Adequate direct application of $\mathrm{N}$ is therefore suggested for increasing yields of ratoon crop.

\section{Fertigation for enhancing sugarcane production}

Sugarcane being a giant crop producing huge quantity of biomass generally demands higher amounts of nutrient elements. A large number of research experiments have clearly demonstrated that for producing higher cane and sugar yields on a sustainable basis application of adequate amounts of fertilizer nutrients viz. nitrogen, phosphorous and potassium is essential. Bakker (1992) reported that sugarcane can remove about $300 \mathrm{~kg}$ nitrogen/ha/season from the soil $(126 \mathrm{Kg}$ nitrogen/feddan/season). Therefore, adequate $\mathrm{N}$ supply should be made available to the crop in the soil from the start of tillering phase. Further, Papadopoulos (1996) speculated that the crop requirement for $\mathrm{N}$ is higher in early grand growth period. This facilitates cane formation, checks tiller mortality and promotes cane growth. It is well-known fact that, water and fertilizer are the most important inputs to boost the sugarcane production, but due to indiscriminate use of available irrigation water and imbalanced application of fertilizers through the conventional methods, most of the sugarcane growing fertile soils have become saline, resulting in low productivity and nutrient loss.

Application of commercial fertilizers is an economic necessity on many soils to promote crop production with nitrogen, phosphorous and potassium being the common fertilizer elements. Nitrogen promotes rapid succulent growth; phosphorus gives early root growth, blooming, and resistance to pest and weather damage. Potassium lends toughness and strength and pest resistance to plants. Fertigation using furrow irrigation is a costeffective and simple method of applying fertilizer across the field. Significant benefits from fertigation cannot be expected unless the irrigation system design is optimized to meet local soil conditions (Beth and Filters, 1981). Hence, there is an urgent need to manage both the resources very efficiently.

The only option to efficiently manage water and fertilizer is the adoption of microfertigation technology for increasing water use efficiency up to $70-95 \%$ and saving in nutrients by $40-50 \%$ which is of great importance at national level (Burt et al., 1995; Meyer and Wood, 2000).

By the year 2025 with the ever-increasing population pressure it is necessary to increase total production of sugarcane above 415 million tonnes (mt). It means that it is necessary to reach productivity from 70 to 100 t/ha with a recovery from 10 to $11 \%$. This challenge could be possible only through the adoption of fertigation technology on a wide scale (Wahab, 2014). It is observed that, area under micro-irrigation in sugarcane crop is increasing day by day. 
Table.1 Comparison of multi-row weeder with manual weeding in sugarcane

\begin{tabular}{|c|c|c|c|c|c|}
\hline \multirow[t]{2}{*}{ S. No. } & \multirow{2}{*}{$\begin{array}{c}\text { Method of } \\
\text { weeding }\end{array}$} & \multirow[t]{2}{*}{ Weeding } & \multicolumn{2}{|c|}{ Field coverage } & \multirow{2}{*}{$\begin{array}{l}\text { Operational } \\
\text { cost }(\mathrm{Rs} / \mathrm{ha})\end{array}$} \\
\hline & & & (ha/hour) & (ha/day) & \\
\hline \multirow[t]{2}{*}{1} & \multirow[t]{2}{*}{ Manual weeding } & $\begin{array}{c}\text { First } \\
\text { weeding }\end{array}$ & 0.006 & 0.05 & 3600 \\
\hline & & $\begin{array}{l}\text { Second } \\
\text { weeding }\end{array}$ & 0.007 & 0.06 & 3450 \\
\hline \multicolumn{3}{|c|}{ Total } & & & 7050 \\
\hline \multirow[t]{2}{*}{2} & \multirow[t]{2}{*}{ Multirow weeder } & $\begin{array}{c}\text { First } \\
\text { weeding }\end{array}$ & 0.250 .28 & 2.00 & 1800 \\
\hline & & $\begin{array}{c}\text { Second } \\
\text { weeding }\end{array}$ & & 2.24 & 1600 \\
\hline \multicolumn{3}{|c|}{ Total } & & & 3400 \\
\hline
\end{tabular}

(Source: Anonymous, 2006)

Fig.1 High throughput in vitro micropropagation of sugarcane cultivar $\mathrm{CoPb} 91$; a) Initiation of in vitro propagation from spindle leaf roll segment; b) Direct adventitious shoot initiation; c) Shoot multiplication resulting in clump formation; d) Shoot multiplication-cumelongation; e) Root induction; f) Hardening of rooted clumps; g) Separation of transplantable plantlets and h) Transfer to soil (Kaur and Sandhu, 2014).
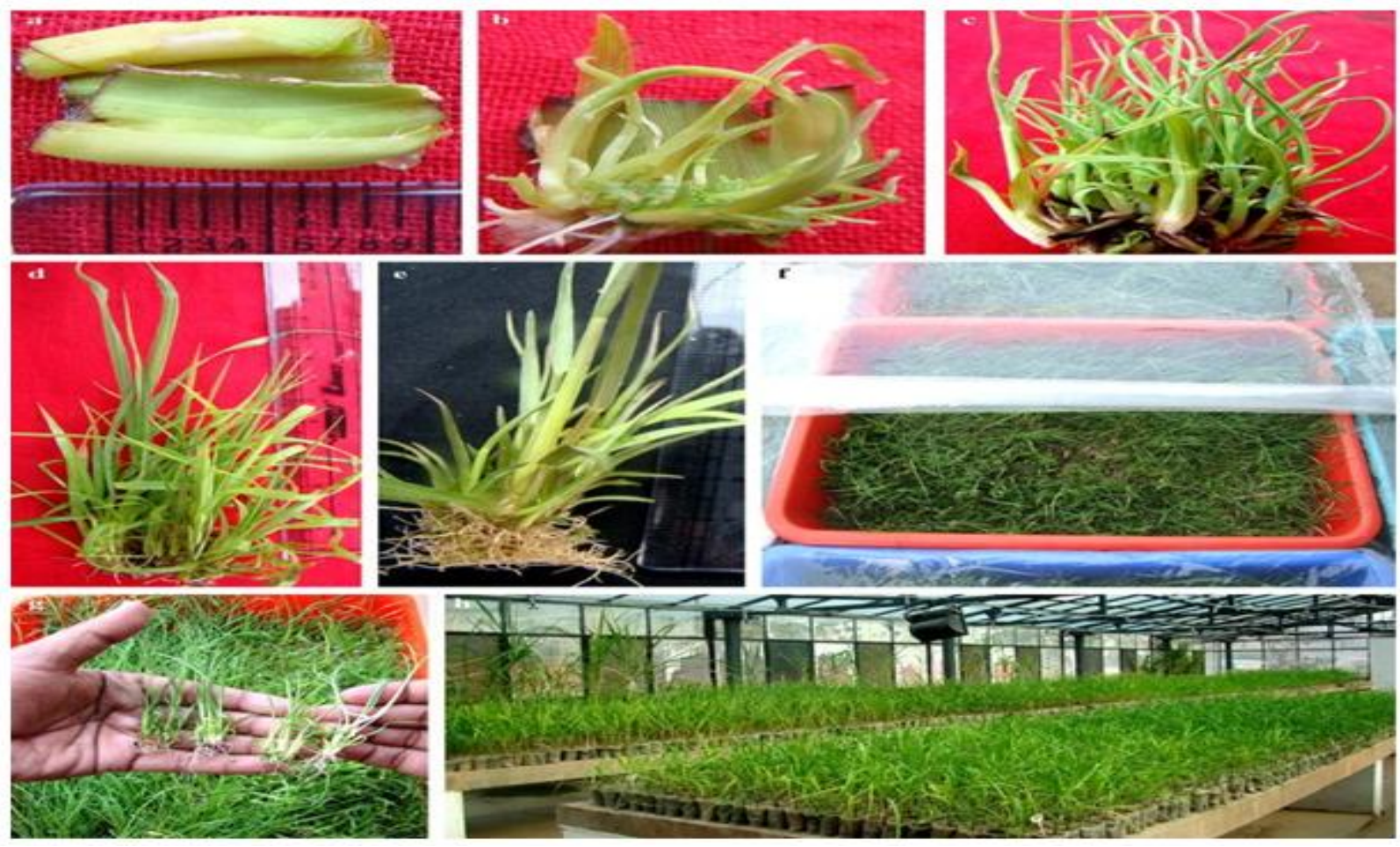
Table.2 Effect of bud chip method of sugarcane planting on cane yield

\begin{tabular}{|c|c|c|c|c|c|c|c|}
\hline Technology & $\begin{array}{c}\text { Survival } \\
(\%)\end{array}$ & $\begin{array}{l}\text { Number } \\
\text { of tillers } \\
\text { bud }^{-1}\end{array}$ & $\begin{array}{l}\text { Number of } \\
\text { millable } \\
\text { canes } \\
\text { clump }^{-1}\end{array}$ & $\begin{array}{c}\text { Yield } \\
\left(t^{\prime} \mathbf{h a}^{-1}\right)\end{array}$ & $\begin{array}{c}\% \text { of } \\
\text { increase } \\
\text { in cane } \\
\text { yield }\end{array}$ & $\begin{array}{c}\text { Production } \\
\text { efficiency } \\
\left(\text { kg ha }^{-1}\right. \\
\left.\text { day }^{-1}\right)\end{array}$ & $\begin{array}{c}\text { Extensio } \\
\text { n gap }\end{array}$ \\
\hline $\begin{array}{c}\text { Improved } \\
\text { practice (Bud } \\
\text { chip method) }\end{array}$ & 93.21 & 7.3 & 14.2 & 129.2 & 39.7 & 421.8 & 36.7 \\
\hline $\begin{array}{c}\text { Farmers } \\
\text { practice } \\
\text { (Conventional } \\
\text { method) }\end{array}$ & 68.4 & 9.2 & 8.5 & 92.5 & - & 280.3 & - \\
\hline
\end{tabular}

(Source: Samant, 2017)

However, application of WSF (Water Soluble Fertilizer) through micro-irrigation system is not adopted by many farmers due to lack of knowledge and unavailability of research information on usage of $100 \%$ solid soluble fertilizers (Manikandan et al., 2019). Introduction of drip fertigation increases the yield of crops by three times and saving of fertilizer by 30 per cent (Deshmukh et al.,.1996, Sivanappan and Ranghaswam 2005) Sub Surface Drip Irrigation (SSDI) is becoming popular nowadays because most favourable moisture and nutrient environment can be maintained in the root zone in SSDI. Because of the long-standing crop, SSDI is being increasingly adopted to sugarcane (Manikandan et al., 2019). Though benefits of SSI under SSDI are realized by farmers, very limited research work has been carried to optimize irrigation and fertilizer levels for SSI under SSDI. In this section, attempt has been made to discuss fertigation technology, its advantages, scope and research needs in connection with agronomical evaluation of nutrient requirement related to crop critical growth stages for ensuring efficient use of water and fertilizer for increasing sugarcane productivity.

Sugarcane is an input intensive and management responsive crop and efficient and judicious input management is pivotal to ascertain remunerative cane yield. Sustained enhancement of soil health including soil organic carbon enrichment contributes substantially to the productivity of plantratoon production system. Practices like addition of biomanures, recycling of crop residues, use of cane trash as mulch, green manuring and intercropping of leguminous crops add to the soil fertility improvement. Such practices have also been found to add to the improvement of soil physical, physicochemical and microbiological properties. Further, enhanced input use efficiency through adoption of appropriate planting technique, micro irrigation techniques, site specific nutrient management, planting geometry, quality seed cane production and slow release nitrogenous fertilizers effectively reduces the cost of cultivation and brings about additional profit to the growers. The benefits of sugar cane growing are enormous to the millers and government ranging from taxes and balancing for the economy. However, for the small scale out growers they have to brace themselves with enormous challenges ranging from exploitation by the middle men, high interest rates on loans offered by the millers, poor planting materials that take along period to mature, food insecurity and generally poverty. 
If there is one success that the People's Parliament achieved is initiating dialogue between different stakeholders in the sugarcane sub-sector to harmonize approaches in the sub-sector to ensure that the rights of the out-growers are protected and that sugarcane growing does not subdue food production.

Although food security and nutrition are often used to justify agricultural interventions, there has been relatively little intentionality in the design of such interventions to ensure that food security and nutrition impacts are positive and significant. The studies discussed in this paper, however, indicate that such impacts can often be anticipated, and that sugarcane projects can be oriented in ways that maximize positive impacts. While reducing household food insecurity may be a more direct result of such an intentional orientation, reduced malnutrition may also be possible in some projects. Efforts are therefore needed to sensitize those responsible for the design of agricultural projects, and to increase awareness among senior agriculture officials in governments and international assistance organizations. As part of this sensitization, it should be noted that while it is clear that agricultural interventions can significantly affect food security and sometimes nutrition, there is also evidence that a healthier, betternourished work force can help to increase agricultural productivity where labor is one of the limiting factors in the production process.

\section{References}

Abdel-Wahab, D. M. 2014. Introduction of fertigation in sugarcane production for optimization of water and fertilizers use. Agric. Sci. 5: 945-957.

Abdullah, M., M. A. Alam, M. A. Rahman and M. N. A. Siddiquee. 2006. Evaluation of tobacco intercropping as botanical pesticides in controlling borer pests in sugarcane. Bangladesh J Sugarcane 28:9-
13.

Acreneaux, G. 1967. Cultivated sugarcanes of the world and their botanical derivation. Proc. International Society Sugar Cane Technologists (ISSCT) 12: 844-854.

Ahmed, T., M. K. Bashar, M. M. Biswas, M. Abdullah and M. N. Kashem. 2007. Performance of sugarcane with double intercrops in tista meander floodplain Soils. Bangladesh J Sugarcane 29: 56-59.

Akinyemi, D. and A. Adewale. 1984. Effect of incubation temperature and different sources of $\mathrm{N}$ and $\mathrm{P}$ on decomposition of saw dust in soil. Biological Wastes 11: 293-306.

Ali, A., S. Naz, F. Siddiqui and J. Iqbal. 2008. An efficient protocol for large scale production of sugarcane through micropropagation. Pak. J. Bot. 40(1): 139-149

Anonymous. 2006. Tractor drawn three row rotary weeder. AICRP on farm implements and machinery, Extension Bulletin No.CIAE/FIM/2006/61

Anonymous. 2019. Package of practices for crops of Punjab- Kharif, Punjab Agricultural University, Ludhiana. Pp 7793.

Artschwager, E. and E. W. Brandes. 1958. Sugarcane. Agricultural Hand Book 122. US Govt Printing Office, Washington DC. 307.

Avivi, S., S. S. Slameto and R. A. Ramadhan. 2016. Physiological characters of sugarcane after flooding Stress. Agriculture and Agricultural Science Procedia 9: 31 39

Babu, M. V. S., C. Mastan Reddy, A. Subramanyam and D. Balaguruvaiah. 2007. Effect of integrated use of organic and inorganic fertilizers on soil properties and yield of sugarcane. Journal of the Indian Society of Soil Science 55 (2): 161166.

Bakker, M. 1999. Sugarcane Cultivation and Management. Kluwer Academic/ Plenum Publishers, New York

Barnes, A. C. 1974. The Sugar Cane, 2nd edn. Leonard Hill Books., Aylesbury

Belete, G. 2017. Review on In vitro propagation 
of sugarcane to advance the value of tissue culture. Agri Res \& Tech: Open Access J. 5(4): $\quad 555670 . \quad$ DOI: 10.19080/ARTOAJ.2017.05.555670

Beth, F. and A. Filters. 1981. Fertigation gains increasing acceptance. Irrigation Farmer 8:2- 16.

Bhaduri, A. 2008. Future Food Grain Production-Anik Bhaduri.doc

Bhatt, R. and Hossain, A. 2019. Concept and consequence of evapotranspiration for sustainable crop production in the Era of climate change. In: Advanced Evapotranspiration Methods and Application. Open tech, England. 1-13.

Binbol, N. L., A. A. Adebayo and E. H. KwomNdung. 2006. Influence of climatic factors on the growth and yield of sugarcane at Numan, Nigeria. Climate Research 32: 247-252

Boddey, R. M., O. C. de Oliveira, S. Urquiaga, V. M. Reis, F. M. de Olivares, V. L. D. Baldani, J. Dobereiner. 1995. Biological nitrogen fixation associated with sugarcane and rice: contributions and prospects for improvement. Plant and Soil 174: 195-209.

Bos, M. G. 1985. Suumary of ICID definations of irrigation efficiency. ICID Bull. 34, 2831

Box, H. E. 1953. List of sugarcane insects: A synanymic catalogue of sugarcane insects and mites of the world and their insect parasites and predators arranged systematically. London. Common wealth Institute of Entomology.

Budhar, M. N. 2005. Leaf color chart with nitrogen management in direct seeded puddled rice (Oryza sativa L). Fertilizer News 50:41-44.

Bull, T. A. and K. T. Glasziou. 1963. The evolutionary significance of sugar accumulation in Saccharum. Australian Journal of Biological Sciences 16: 737742.

Burt, C, K. O'Connor and T. Ruehr. 1995. Fertigation. California Polytechnic State University, Irrigation Training and Research Center, San Luis Obispo.

Carr, M. K. V. and J. W. Knox. 2011. The water relations and irrigation requirements of sugar cane (Saccharum officinarum): A review. Expl Agric. 47 (1): 1-25

Carter, M. R., D. A. Holmstrom, L. M. Cochrane, P. C. Brenton, J. A. Roestel, D. R. Van Langille, W.G. Thomas and J.A. Van Roestel. 1996. Persistence of deep loosening of naturally compacted subsoils in Nova Scotia. Canadian Journal of Soil Science 76(4): 541-547

Carvalho, M., R. Serralheiro, J. Corte-Real and P. Valverde. 2015. Implications of climate variability and future trends on wheat production and crop technology adaptations in southern regions of Portugal. Water Util. J. 9: 13-18.

Chen, J.C.P. 1985. Cane Sugar Handbook (Eleventh Edition). John Wiley and Sons Inc. New York.

Chennakesavulu, B. 2014. Performance evaluation of raingun sprinkler irrigation system with different operating pressures. International Journal of Food, Agriculture and Veterinary Sciences

Coleman, R. E. 1970. New plants produced from callus tissue culture. In: Sugarcane Research. 1970 Report. U.S. Dept. Agric. Res. Serv. Pl. Sci. Res. Div. P. 38.

Deshmukh, A. S., P. P. Shinde and S. B. Jadhav. 1996. Fertigation under drip irrigation for sugarcane. In: All India Seminar on Modern Irrigation Techniques, Bangalore. Pp. 217-219

Dinka, M. O. 2016. Evaluating the adequacy performance of sprinkler irrigation systems at Finchaa sugar cane plantation, Eastern Wollega zone (Ethiopia). Irrig. Drain. 65: 537-548.

Dlamini, M. 2005. Experience with drip irrigation on smallholder sugarcane irrigation schemes in Swaziland. Proc. S. Afr. Sugar Technol. Assoc. 79: 463-472.

Dunckelman, P. H. and R. D. Breaux. 1970. New sugarcane breeding clones from Indian crosses evaluated at Houma, Louisiana, 1966-1969. International Sugar Journal. 72: 43-44.

El-Berry, A. M., E. 1. Ebaby, S. S. Hassan and S. M. Fattouh. 2006. Performance of locally 
developed surface irrigation in sugarcane production. Misr J. Agric. Eng. 23: 169191.

Elena Sánchez Elordi, Eva M. Díaz, Robertode Armas Rocío, Santiago Borja Alarcón, Carlos Vicente, María Estrella Legaz. 2020.. Effects of abiotic stresses on sugarcane plants with emphasis in those produced by wounds and prolonged postharvest periods. In: Plant Life Under Changing Environment. Pp. 251-269

FAO. 1981. Agriculture towards 2000. Rome

Gawander, J. 2007. Impact of climate change on sugar-cane production in Fiji. WMO Bull. 56(1).

Goebel, F. R. and N. Salam. 2011. New pest threats for sugarcane in the new bioeconomy. Current Opinion in Environmental Sustainability 3:81-89.

Govaerts Sayre, K. D. and J. Deckers. 2005. Stable high yields with zero tillage and permanent bed planting. Field Crop Res. 94: 33-42.

Gregory, P. J., S. N. Johnson and J. S. Ingram. 2009. Integrating pests and pathogens into the climate change debate. Journal of Experimental Biology 60(10):2827-2838

Gulati, A. and P. Banerjee. 2016. Emerging Water Crisis in India: Key Issues and Way Forward. Indian Journal of Economics, Special Centennial Issue, 681-704.

Gunarathna, M. H. J. P., K. Sakai, T. Nakandakari, M. Kazuro, T. Onodera, H. Kaneshiro, H. Uehara and K. Wakasugi. 2018. Optimized subsurface irrigation system: The future of sugarcane irrigation. Water 10: 1-14

Gunarathna, M. H. J. P., K. Sakai, T. Nakandakari, M. Kazuro, T. Onodera, H. Kaneshiro, H. Uehara and K. Wakasugi. 2017. Optimized subsurface irrigation system (OPSIS): Beyond traditional subsurface irrigation. Water 9: 599-612.

Hall, D. 1988. Insects and mites associated with sugarcane in Florida. Florida Entomologist 71:138-150

Hanafy, M., A. Mahrous and M. Z. El Garib. 2008. Water requirements for irrigated sugarcane under trickle irrigation systems.
Misr J. Agric. Eng. 25: 1343-1357.

Hendre, R. R., R. S. Iyyar, M. Katwal, S. S. Khuspe and A. F. Mascarenhas. 1983. Rapid multiplication of sugarcane through tissue culture. Sugarcane. 1: 5-7.

Hendre. R. R., A. F. Mascarenhas, A. L. Nadgir, M. Pathak and V. Jagannathan. 1975. Growth of sugarcane mosaic virus free sugarcane plants from apical meristems. Indian Phytopathol. 28: 175-178.

Hossain. A., M. K. Rahman, M. L. Kabir, M. A. Matin and M. J. Alam.1995. Performance of soybean and some other crops as intercrops with paired row transplanted sugarcane. Bangladesh J Sugarcane 17: 119-122.

Hunsigi, G. 1993. Production of Sugarcane, Theory and Practice,. Heidelberg: Springer-Verlag. xviii $+245 \mathrm{pp}$

Ibeawuchi, I. I. 2007. Intercropping: A food production strategy for the resource poor farmers. Nat Sci 5: 46-59.

Imran, M., A. Ali., M. Waseem, M. Tahir, A. U. Mohsin et al., 2011. Bio-economic assessment of sunflower-mungbean intercropping system at different planting geometry. Inter Res J Agric Sci and Soil Sci 1: 126-136.

Inman-Bamber, N. G. and D. M. Smith. 2005. Water relations in sugarcane and response to water deficits. Field Crops Research 92:185-202.

Islam, M. O. and S. Islam. 2018. Sugarcane Cultivation is Highly Profitable with Potato and Mungbean as Successive Intercrops without Loss in Cane Quality. J Plant Bio Agric Sci 2 (1): 2

Jackson, P. A. 2005. Breeding for improved sugar content in sugarcane. Field Crops Res. 92: 109-117

Jain, R., A. Chandra, A. K. Srivastava and S. Solomon. 2014. Bud chip technology for rapid seed multiplication and improving cane yield, Indian Farming 63(10):2-3.

Jalaja, N. C., D. Neelamathi and T. V. Sreenivasan. 2008. Micropropagation for quality seed production in sugarcane in Asia and the Pacific. Food and Agriculture Organization of the United Nations, Asia- 
Pacific Consortium on Agricultural Biotechnology, New Delhi

Jat, M. L., S. S. Pal, A. V. M. Subba Rao, K. Sirohi, S. K. Sharma and R. K. Gupta. 2004. Laser land levelling: The precursor technology for resource conservation in irrigated ecosystem of India. Proceedings of the National Conference on Conservation Agriculture, New Delhi, India. 9-10.

Jones, C. A., L. T. Santo, G. Kingston and G. J. Gascho. 1990. Sugarcane. In: Irrigation of Agricultural Crops (Eds. B. A. Stewart and D. R. Nielsen). Agronomy No. 30, Wisconsin, USA, American Society of Agronomy.

Kashem, M. N., G. M. A. Hossain, M. A. Jabber, M. K. Bashar and K. S. Alam. 2007. Performance of selected winter vegetables as first and sun hemp as second intercrop with paired row sugarcane. Bangladesh J Sugarcane 29: 68-73.

Kaur, A. and J. S. Sandhu. 2014. High throughput in vitro micropropagation of sugarcane from spindle leaf roll segments: cost analysis for agri-business industry. Plant Cell Tissue Organ Cult 120:339-350

Kaushal, A., R. Patole and K. G. Singh. 2012.. Drip irrigation in sugarcane: A review. Agric. Rev. 33: 211-219

Khan, N. U., M. H. Rahman, R. C. Kabiraj, M. A. Islam and G. C. Paul. 2005. Performance of potato and maize as first intercrop, dhaincha (green manure) as second intercrop with paired row sugarcane in old Himalayan piedmont plain. Bangladesh J Sugarcane 24: 78-81.

Kiritani, K. 2006. Predicting impacts of global warming on population dynamics and distribution of arthropods in Japan. Population Ecology 48:5-12.

Knox. J. W., J. A. Rodríguez Díaz, D. J. Nixon, and M. A. Mkhwanazi. 2010. Preliminary assessment of climate change impacts on sugarcane in Swaziland. Agric. Syst. 103:63-72.

Kumar, S., S. K. Saini, and A. Bhatnagar. 2012. Effect of subsoiling and preparatory tillage on sugar yield, juice quality and economics of sugarcane (Saccharum species hybrid) in sugarcane plant-ratoon cropping system. Sugar Tech 14(4):398-404

Lee, T. S. G. 1987. Micro-propagation of sugarcane (Saccharum spp). Plant Cell Tiss Org Cult 10:47-55

Linsley, C. M. and F. C. Bauer. 1929. Test your soil for acidity. Univ. of Illinois. Agric. Exp. Stn. Circ. 346.

Mahesh, R., R. N. Asoka and H. A. Archana. 2016. Performance of surface and subsurface drip fertigation on yield and water use efficiency of sugarcane. In Proceedings of the 2nd World Irrigation Forum, Chiang Mai, Thailand, 6-8 November.

Malavolta, E. 1994. Nutrient and fertilizer management in sugarcane. International Potash Institute Bulletin No. 14. International Potash Institute, Basel, Switzerland;

Mall, A. K., V. Misra, D. Singh, M. Kumar and A. D. Pathak. 2018 Methods and procedures for high yielding seed cane production. International Journal of Agriculture Sciences 10 (14):6660-6664

Mamet, L. D. and N. W. Galwey. 1999. A relationship between stalk elongation and earliness of ripening in sugarcane. Expl. Agric. 35:283-291.

Mamun, A., H. Sikdar, K. Paul, M. Mizanur and D. Rahman et al., 2004. In vitro micropropagation of some important sugarcane varieties of Bangladish. Asian Journal of Plant Sciences 3(6): 666-669

Manikandan, M., G. Thiyagarajan, S. Thenmozhi, S. K. Natarajan, J. Bhuvaneswari, and N. K. Prabhakaran. 2019. Optimization of irrigation and fertigation scheduling for sustainable sugarcane initiative (SSI) through subsurface drip irrigation in Western Zone of Tamil Nadu. Curr Agri Res. 7(1): https://bit.ly/2OYgTds

Marin, F. R., J. W. Jones, A. Singels, F. Royce, E. D. Assad, G. Q. Pellegrino and F. Justino. 2013. Climate change impacts on sugarcane attainable yield in southern Brazil. Climatic change, 117(1-2), 227-239 
Martínez, H., E. Sara van, J. P. da Cunha, M. G. Joaquim, J.M. Walter, A. F. Andre. 2013. Analysis of socio-economic impacts of sustainable sugarcane-ethanol production by means of inter-regional Input-Output analysis: demonstrated for Northeast Brazil. Renewable and Sustainable Energy Reviews 28(C): 290-316.

Mazibuko, N.W., P. L. Greenfield and M. A. Johnston. 2002. The effect of different furrow irrigation regimes on infiltration and sugarcane yield at Ubombo. Proc. S. Afr. Sugar Technol. Assoc. 76: 196-206.

Meyer, J. H. and A. W. Wood. 2000. Soil Management Research for Sustainable Cane Production in the 21st Century. In: Wilson J R, Hogarth D M, Campbell J A and Garside A L, (Eds.) Sugarcane: Research towards Efficient and Sustainable Production. CSIRO, Brisbane, 343-358.

Miller, J. D. and N. I. James. 1977. Maturity of six sugarcane varieties in Florida. Proc. Am. Soc. Sugar Cane Technol. 7:107-111.

Narayanamoorthy, A. 2005. Economics of drip irrigation in sugarcane cultivation: Case study of a farmer from Tamil Nadu. Indian J Agric Econ 60: 235-248.

Olaoye, J. O. and Adikanae, T. A. 2006. Development and evaluation of power tractor drawn rotary weeder. Proc Nig Soc Agric Engg 3: 189-199.

Papadopoulos, I. 1996. Micro-irrigation Systems and Fertigation. In: Pereira, L. S., et al., Eds., NATO ARW on Sustainability of Irrigated Agriculture, Kluwer Academia Publishers, New York, 309-322.

Parihar, S. S. 2004.. Effect of crop establishment method, tillage, irrigation and nitrogen on production potential of rice (Oryza sativa)wheat (Triticum aestivum) cropping system. Indian Journal of Agronomy 49(1): $1-5$.

Pathak, A. D. 2009. Quality seed cane in sugarcane. In: (A K Shrivastava etal. Eds). Pp 14-17.

Pierce, J. F. and N. Peter. 1999. Aspects of precision agriculture. Adv. Agron. 67:1-85.

Ping, C. L., G. J. Michaelson, J. M. Kimble and D. A. Walker. 2005. Soilacidity and exchange properties of cryogenic soils in Arctic Alaska. Soil Sci. Plant Nutr. 51(5): 649-653.

Pires, R. C. M., E. A. A. Barbosa, F. B. Arruda, T. J. A. Silva, E. Sakai and M. G. A. Landell. 2012. Subsurface Drip Irrigation in Different Planting Spacing of Sugarcane; Geophysical Research Abstracts. In Proceedings of the EGU General Assembly, Vienna, Austria, 22-27 April 2012.

Price, S. 1967. Interspecific hybridization in sugarcane breeding. Proc. International Society Sugar Cane Technologists (ISSCT) 12: 1021-1026.

Ram, M., B. N. Chatterjee, R. L. Yadav and D. V. Singh. 1988. Minimizing volatilization and leaching losses of nitrogen by different nitrogen carriers in Japanese mint. J. Agric. Sci., 110: 415-418.

Ramesh, P. and M. Mahadevaswamy. 2000. Effect of formative phase drought on different classes of shoots, shoot mortality, cane attributes, yield and quality of four sugarcane cultivars. J. Agron. Crop. Sci. 185:249-258.

Raper, R. L., D. W. Reeves and E. C. Burt. 1998. Using in-row subsoiling to minimize soil compaction caused by traffic. Journal of Cotton Science 2: 130-135

Razzaque, M. A., S. Rafiquzzaman, M. M. Bazzaz, M. A. Ali and M. M. R. Talukdar. 2007. Study on the intercropping groundnut with chilli at different plant populations. Bangladesh J Agric Res 32: 37-43.

Reddy, S. and P. Sreenivasulu. 2011. Generation of sugarcane streak mosaic virus -free sugarcane (Saccharum spp. hybrid) from infected plants by in vitro meristem tip culture. Eur J Plant Pathol 130:597-604

Robert, P. C. 1999. Precision agriculture: Status and research needs. In Proceedings of the 2nd European Conference on Precision Agriculture. Ed. J Stafford. Odense, Danemark. SCI, London, UK.

Robert, P. C. 2002. Precision agriculture: A challenge for crop nutrition management. Plant Soil. 247(1):143-149 
Rosegrant, M. W., S. Msangi, C. Ringler, T. B. Sulser, T. Zhu and S. A. Cline. 2008. International Model for Policy Analysis of Agricultural Commodities and Trade (IMPACT): Model description. Washington, D.C.: International Food Policy Research Institute.

Sahoo, H. K. 2014. Effect of planting methods on yield and economics of sugarcane. National symposium on Management option farm productivity and livelihood security under changing climate, Odisha chapter, ISA, Pp. 221-222

Salokhe, S. 2016. Production of disease free quality sugarcane planting material through micropropagation. Int J Innov Res Sci Eng 2:97-103

Samant, T. K. 2017. Bud chip method: A potential technology for sugarcane (Saccharum officinarum) cultivation. Journal of Medicinal Plants Studies. 5(3): 355-357

Sandhu, S. K., S. S. Gosal, K. S. Thind, S. K. Uppal, B. Sharma, M. Meeta, K. Singh and G. S. Cheema. 2009. Field performance of micropropagated plants and potential of seed cane for stalk yield and quality in sugarcane. Sugar Tech 11:34-38

Sanghera, G. S. and A. Kumar. 2018a. Recent perspectives towards enhancing drought tolerance in sugarcane. Jour Pl Sci Res 34 (1):23-34

Sanghera, G. S., L. Kashyap, R. Kumar, V. Tyagi, Rupinder Pal Singh, O. Singh, K. S. Thind and B. Kumar. (2016 a). CoPb 08212: A high yielding and early maturing sugarcane variety for North Western Zone of India Ind J Sugarcane Tech 31(01): 1015.

Sanghera G S, R. Kumar, V. Tyagi, Rupinder Pal Singh, L Kashyap, O. Singh, K. S. Thind and B. Kumar. 2016 b. CoPb $08217-$ A Promising Mid Maturing Variety of Sugarcane for Punjab, Jour Pl Sci Res 32 (2): 165-171.

Sanghera, G. S. 2020. Sugarcane disorders associated with temperature extremes and mitigation strategies. East African Scholars J Agri Life Sci. 4: 101-114
Sanghera, G. S. and A. Kumar. 2018b. A review on mechanisms, screening and engineering for pest resistance in sugarcane (Saccharum spp). J Pharmacog and Phytochem 2018;7(4S):187-194.

Sanghera, G. S. and P. K. Malhotra. 2018. Engineering Sugarcane (Saccharum spp) for Disease Resistance: Recent Approaches. Research \& Reviews in Biotechnology \& Biosciences 5 (1): 15-28

Sanghera, G. S. and A. Kumar. (2018c) Recent Trends for Managing Disease Menace in Sugarcane (Saccharum spp.). In: Advances in Plant disease Management (Amarendra Kumar et al.,. Eds.), Weser Books, Germany. Pp: 26-49

Sanghera, G. S. and A. Kumar. 2020. Quality seed assurance in sugarcane (Saccharum spp.) for rejuvenation of varietal yield decline using rapid multiplication techniques (rmts). International Journal of Current Research. 12 (5):11717-11726

Sanghera, G. S., A. Kumar and R. Bhatt. 2020. Prospects of precision farming in sugarcane agriculture to harness the potential benefits. Current Journal of Applied Science and Technology 39(2): 112-125.

Sanghera, G. S., Rupinder Pal Singh, O. Singh and V. Tyagi. 2018. Initiatives for Sustainable Sugarcane Farming in Punjab. Jour Pl Sci Res 34 (2) 137-152

Sanghera G. S. and V. K. Sharma. 2011. A critical review on morpho-physiological and molecular aspects associated with cold stress in plants. Elixir Agriculture 39: 5065-5075

Sanghera, G. S., H. Singh and R. Bhatt 2018. Impact of water stress on manifestation of cane yield components and physiological traits in sugarcane (Saccharum sp. Hybrid complex). International J Agrl Sci. 10(5):5284-5290.

Sanghera, G. S., V. Tyagi, R. Kumar and K. S. Thind. 2014. Genetic variability for cane yield, earliness and quality traits in sugarcane under subtropical region of India. International Journal of Current Research. 6(8):7763-7765. 
Santos, D. L. and P. C. Sentelhas. 2012. Climate change scenarios and their impact on the water balance of sugarcane production areas in the State of São Paulo, Brazil. Ambi-Agua Taubaté 7:717.

Sauvaire, D. and R. Galzy. 1978. Micropropagation de la canne a sucre par bouturage in vitro. Comptes Rendus de L'Academie des Sciences. Ser. 287: 467470.

Shahi, H. N., T. K. Srivastava, R. Ramakant and A. Suman. 2003. Soil behaviour and growth and productivity of sugarcane ratoon as influenced by trash management and preceding intercrops. Indian Journal of Agronomy, 48(4):271-273

Shanthy, T. R. 2012. Strategies for effective dissemination of appropriate technologies to sugarcane growers in India. Sugar Tech 13(4): 354-359

Shanthy, T. R. and M. Venkatesaperumal. 2018. Bio-fertilizers for sustainable sugarcane production: a socio-economic analysis. Journal of Sugarcane Research 8 (2): 127 - 137

Shanthy, T. R., M. Chinnapillai and L. Saravanan. 2019. Integrated pest management in sugarcane - a socio economic analysis. International Journal of Science, Environment and Technology. 8 (4): $834-839$

Sharma, A. K., R. K. Sharma, and K. S. Babu 2004. Effect of planting options and irrigation schedules on development of powdery mildew and yield of wheat in the North Western plains of India. Crop Prot. 23: 249-253.

Sharma, S. K., M. L. Jat and C. Biswas. 2005. Components of precision farming. Indian J. Fertilizers. 1:13-26.

Shih, S. F. 1989. Relating calculated leaf area index, evapotranspiration and irrigation method of sugarcane. Agron J 81: 111115

Shinde, P. P. and A. S. Deshmukh. 2007. Sugarcane nutrition through rain gun sprinkler irrigation. Proc. Int. Soc. Sugar Cane Technol. 26: 481-484.
Shrivastava, A. K., A. K. Shrivastava and S. Solomon. 2011. Sustaining sugarcane productivity under depleting water resources. Current Sciences 10(06), 748754.

Shrivastava, T. K., M. B. Pandey and S. K. Awasthi. 2006. Effect of planting methods and nutrient management on growth, yield and rejuation of declined sugarcane (Saccharum complex hybrid). Indian J. Agri. Sci., 01(76): 103- 107.

Shukla, A K, J. K. Ladha, V. K. Singh, B. S. Dwivedi, S. K. Sharma, V. Balasubramanian, R. K. Gupta, Y. Singh, H. Pathak, P. S. Pandey, A. T. Padre and R. L. Yadav. 2004. Calibrating the leaf color chart for nitrogen management in different genotypes of rice and wheat in a systems perspective. Agron. J.96: 1606-1621.

Shukla, S. K. and M. Lal. 2003. Productivity and economics of sugarcane based production systems in subtropical India. Indian J. Agron. 48: 16-19.

Singh, A., N. Aggarwal, G. S. Aulakh and R. K. Hundal. 2012. Ways to maximize the water use efficiency in field crops - A review. Greener Journal of Agricultural Sciences 2(4): 108-129

Singh, S. N., R. L. Yadav, M. Lal, A. K. Singh, G. K. Singh, Om Prakash and V. K. Singh. 2011. Assessing feasibility of growing sugarcane by a polythene bag culture system for rapid multiplication of seed cane in sub-tropical climatic conditions of India. Plant Production Science 14(3): 229232.

Singh, V., S. K. Kothari and H. N. Tripathi. 1986. Studies on intercropping in sugarcane in central Uttar Pradesh. Indian Sugar J 35: 559-562.

Sinha, M. K., D. P. Sinha and H. Sinha. 1977. Organic matter transformations in soils. V. Kinetics of carbon and nitrogen mineralization in soils amended with different organic materials. Plant and Soil, 46: 579-590.

Sivanappan, R. K. and M. V. Ranghaswami. 2005. Technology to take 100 tons per acre in Sugarcane. Kissan World. 32:35-38. 
Sreenivasan, T. V. 1995. Micropropagation of newly released varieties for quality seed production. Kisan World. 22:22-23.

Sreenivasan, T. V. and N. C. Jalaja. 1981. Utilization of tissue culture technique in sugarcane improvement. C. Meristemculture. Annual Report. Sugarcane Breeding Institute, Coimbatore, 68.

Srivastava, T. K. and R. L. Yadav. 2017. Resource conservation technologies for input use efficiency and sustainable yield of sugarcane. Indian Journal of Sugarcane Technology 32(01): 1-6.

Stafford, J. V. 1996. Essential technology for precision agriculture. In: Robert P C, Rust R H, Larson W E. (Eds.), Precision Agriculture. Proceedings of the third International Conference on Precision Agriculture Minneapolis. 595-604.

Sugiyarta, E. and S. Winarsih. 2008. Rapid propagation of sugarcane planting materials by using stratified Rayungan method. Sugar Tech 11 (1): 22-27.

Sundara, B. 2000. Sugarcane Cultivation. Vikas Publications Pvt. Ltd. P. 302.

Tawar, P. N. 2006. Tissue culture plantlets in sugarcane seed production. In: Sugarcane Seed Certification Manual. First State Level Training Programme for Officers of Maharashtra Seed Certification Agency. Vasantdada Sugar Institute, Pune, 2006, 27-30.

Thrikawala, S., A. Weersink, G. Kachanoski and G. Fox. 1999. Economic feasibility of variable-rate. J Economics. 81:914-927.

Verma, R. S. 2004. Sugarcane Production Technology in India, International. Book
Distributing Co., Lucknow, Pp. 628.

Viswanathan, R. and G. P. Rao. 2011. Disease scenario and management of major sugarcane diseases in India. Sugar Tech. 13(4). DOI: $10.1007 / \mathrm{s} 12355-011-0102-4$

Williams, J. R., J. R. Metcalfe, R. W. Mungomery and R. Mathes. 1969. Pests of sugarcane. Amsterdam, Elsevier.

Yadav, D. V., T. Singh and A. K. Srivastava. 1987. Recycling of nutrients in trash with $\mathrm{N}$ for higher cane yield, Biological Wastes, 20:133-141.

Yadav, D.V. 2009. Quality seed cane in sugarcane. In: (A K Shrivastava et al., Eds.). Pp. 61-67.

Yadav, R. L. and S. R. Prasad. 1992. Conserving the organic matter content of the soil to sustain sugarcane yield. Experimental Agriculture 28:57-62.

Yadav, R. L. 1985. Enhancing recoveries of fertilizer $\mathrm{N}$ applied to sugarcane, Biological Memoirs 11: 135-142.

Yadav, R. L., A. Suman, S. R. Prasad and O. Prakash 2009. Effect of Gluconacetobacter diazotrophicus and Trichoderma viride on soil health, yield and N-economy of sugarcane cultivation under subtropical climatic conditions of India. European Journal of Agronomy 30 (4): 296-303.

Yadav, R. L. 1991. Sugarcane production technology. Constraints and potentialities. IBH, New Delhi, 291 pp

Yates, R. A. and R. D. Taylor. 1988. Water-use efficiencies in relation to sugarcane yields. Sugarcane 1: 6-10

Zadrazil, H. 1990. Dragline irrigation: practical experience with sugarcane. Agric Water Management 17: 25-35.

\section{How to cite this article:}

Gulzar S. Sanghera. 2021. Strategies to Enhance Input Use Efficiency and Productivity of Sugarcane through Precision Agriculture. Int.J.Curr.Microbiol.App.Sci. 10(06): 774-801. doi: https://doi.org/10.20546/ijcmas.2021.1006.084 